Research of psychological and pedagogical typologization of mental developmental delay of schoolchildren

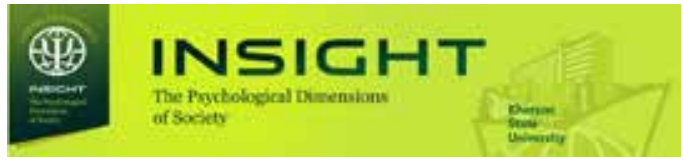

DOI: $10.32999 / 2663-970 X / 2020-4-7$

Link article (Style APA): Prokhorenko L. I. \& Kostenko T. M. (2020). Research of psychological and pedagogical typologization of mental developmental delay of schoolchildren. Insight: the psychological dimensions of society, 4, 111-131. DOI: 10.32999/2663-970X/2020-4-7

Link article (Style DSTU 8302: 2015): Prokhorenko, L. I. \& Kostenko, T. M. Research of psychological and pedagogical typologization of mental developmental delay of schoolchildren. Insight: the psychological dimensions of society, 2020, 4, 111-131. DOI: 10.32999/2663-970X/2020-4-7

UDC 37:159.923-043.84:376.4-057.874

\title{
Research of psychological and pedagogical typologization of mental developmental delay of schoolchildren
}

\author{
Дослідження психолого-педагогічної типологізації \\ затримки психічного розвитку школярів
}

Received: June 23, 2020 Accepted: October 31, 2020

\author{
Prokhorenko Lesia Ivanivna \\ Doctor of Psychology Sciences \\ Mykola Yarmachenko Institute of Special \\ Pedagogy and Psychology, Ukraine \\ lesya-prohor@ukr.net, \\ ORCID 0000-0001-5037-0550 \\ Kostenko Tetyana Mykolayivna \\ Candidate of Psychological Sciences \\ Department of education of children with \\ visual impairments \\ Mykola Yarmachenko Institute of Special \\ Pedagogy and Psychology, Ukraine \\ tanya_t.k@ukr.net, \\ ORCID 0000-0002-4976-1236
}

\begin{abstract}
The study presents an analysis of developmental delay of schoolchildren. It is outlined that the studied state covers the whole mental sphere of the child and is reflected in the peculiarities of the development of cognitive processes, speech defects, immaturity of complex behaviors, shortcomings of purposeful activity against the background of excessive exhaustion, disability, encephalopathy disorders. The purpose of the study is to substantiate a psychological and pedagogical typology of developmental delay of students theoretically; to reveal key ways of organizing and optimizing the education of children with
\end{abstract}

\section{Прохоренко Леся Іванівна} доктор психологічних наук Інститут спеціальної педагогіки і психології імені Миколи Ярмаченка, Україна lesya-prohor@ukr.net, ORCID 0000-0001-5037-0550

\section{Костенко Тетяна Миколаївна} кандидат психологічних наук відділу освіти дітей з порушеннями зору Інститут спеціальної педагогіки і психології імені Миколи Ярмаченка, Україна tanya_t.k@ukr.net, ORCID 0000-0002-4976-1236 
different types of developmental delay; to form recommendations on the most optimal trajectory of choosing an educational institution for them. Research methods - analysis and generalization of the fundamentally important aspects of education reform for people with special needs. To determine the developmental delay of schoolchildren we used $\mathrm{k}$-means cluster analysis, to determine the relationship between motivational, operational and reflexive-evaluative components of educational activities we used Pearson correlation analysis at $\mathrm{p} \leq .01 ; \mathrm{p} \leq .05$. Emphasis is placed on the progress of inclusion in general, the activities of inclusive resource centers (IRC), and preschool education of children with special needs and the realization of the opportunities of such children in the educational environment. Results. It is established that the hierarchy of mental disorders in developmental delay is different from intellectual disability. It has been shown that developmental delay is characterized rather not by deficiencies in one's thinking, in particular in the ability to abstract and generalize, but in the deficiency of "preconditions" of thinking, in cognitive processes: memory, attention, spatial gnosis, other higher cortical functions, and pace of mental processes. Conclusions. It is proved that it is important to ensure the effective integration of children with special educational needs into the educational institution with correctly defined educational trajectory in view of their mental capabilities and educational and cognitive abilities.

Keywords: typology, inclusion, cognitive processes, educational trajectory of the child, inclusive resource center.

\section{Introduction}

Democratic changes in the public life ofthecountryhaveledtoanewvision, understanding and reassessment of many sustainable provisions, including reform and development of education for people with special needs, which is actually reflected in government regulations (Laws of Ukraine "On Education", "On Rehabilitation of Disabled in Ukraine", etc.), which provide for effective measures and programs of state support for children with special needs, creating the necessary conditions for their successful integration into society.

Rapid reform of the education sector encourages the development of educational innovations in the education of children with special needs, which includes modernization of educational programs, затримки психічного розвитку; сформувати рекомендації щодо найоптимальнішої траєкторії вибору для них навчального закладу. Методи дослідження аналізування та узагальнення принципово важливих аспектів реформування освіти осіб 3 особливими потребами. Для дефініції затримки психічного розвитку школярів використано кластерний аналіз методом $k$-середніх, для визначення взаємозв'язку між мотиваційним, операційним та рефлексивно-оцінним компонентами навчальної діяльності застосовано метод кореляційного аналізу r-Пірсона при $\mathrm{p} \leq 0.01 ; \mathrm{p} \leq 0.05$. Акцентовано увагу на поступі інклюзії в цілому, діяльності інклюзивно-ресурсних центрів (ІРЦ), дошкільної і переддошкільної ланок освіти дітей з особливими потребами i, реалізації можливостей таких дітей в освітньому середовищі. Результати. Встановлено, що ієрархія порушень психічних функцій при затримці психічного розвитку інша, ніж при розумовій відсталості. Показано, що при затримці психічного розвитку недосконалим $\epsilon$ не власне мислення, зокрема здатність до абстрагування та узагальнення, а дефіцитарність “передумов" мислення, тобто когнітивних процесів: пам'яті, уваги, просторового гнозису, інших вищих коркових функцій, темпу психічних процесів. Висновки. Обгрунтовано і доведено, що важливе значення для забезпечення ефективної інтеграції дітей з особливими освітніми потребами у навчальний заклад має правильно визначена освітня траєкторія дитини з огляду на її психічні можливості та навчально-пізнавальні здібності.

Ключові слова: типологізація, інклюзія, пізнавальні процеси, освітня траєкторія дитини, інклюзивно-ресурсний центр.

\section{Вступ}

Демократичні зміни в суспільному житті країни зумовили нове бачення, розуміння та переоцінку багатьох сталих положень, зокрема реформування та розвитку системи освіти осіб 3 особливими потребами, що власне відображено в урядових нормативноправових документах (Законах України “Про освіту”, “Про реабілітацію інвалідів в Україні” та ін.), в яких передбачено ефективні заходи та програми державної підтримки дітей з особливими потребами, створення необхідних умов для успішної інтеграції їх у суспільство.

Бурхливе реформування освітньої галузі спонукає до розроблення освітніх інновацій у навчанні дітей з особливими потребами, що передбачає модернізацію освітніх програм,

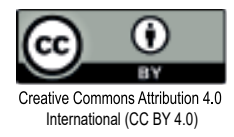


development of organizational aspects of working with such children, selection of adequate methods and techniques of correctional and developmental activities. As a result, a wide range of individual learning trajectories, a system of organizational and methodological tools for quality learning: adapts curricula and plans, methods and forms of learning, uses all available resources to individual educational needs and various formats of training for people with special needs (training).

In view of the above, it seems appropriate to consider in more detail the genesis of the problem of developmental delay, in particular its psychological and pedagogical aspect, as well as implementation.

\section{Theoretical analysis of the problem}

In psychology, the term "developmental delay" refers to a variety of relatively mild developmental disorders, characterized by immaturity of emotional, volitional and cognitive functions with the prospect of their development or compensation.

In the XIX century, well-known psychiatrists M. Lewis, E. Locke (Lewis, 2006; Locke, 2002) define the concept of "infantilism", which means a special delay in psychophysical development, which occurs under the influence of various infections and intoxications. As the main virulent characteristic of infantile children, scientists have identified the immaturity of the emotional and volitional sphere by the type of infantilism and difficulties in acquiring knowledge and ideas at the initial stage of learning. Infantilism is clearly visible in the conditions when a child must fulfill new requirements for him, in particular in the transition from preschool to school. That is, in the concept of infantilism, the authors invest a holistic structure of physical and mental signs of immaturity, which are not characteristic of children of the same age with normative development.

In foreign literature in the context of socio-cognitive theories, children with CPD are considered on the one hand as pedagogically neglected and usually describe their needs as learning difficulties ("educationally disabled", "children with learning disabilities"), on the other - they are defined as unadapt to society, розроблення організаційних аспектів роботи 3 такими дітьми, вибір адекватних методів та прийомів корекційно-розвивальної діяльності, визначення індивідуального напряму розвитку дитини та ін. Як наслідок, створюється широкий діапазон індивідуальних навчальних траєкторій, система організаційно-методичних засобів для якісного засвоєння знань: адаптуються навчальні програми та плани, методи та форми навчання, використовуються всі наявні ресурси до індивідуальних освітніх потреб і різних форматів навчання осіб із особливими потребами (підтримка в навчанні).

3 огляду на вищезазначене видається за доцільне дещо детальніше розглянути ґенезу проблеми затримки психічного розвитку, зокрема їі психолого-педагогічний аспект, а також реалізацію.

\section{Теоретичне аналізування проблеми}

У психології термінами "затримка темпу психічного розвитку”, “затримка психічного розвитку” позначаються різноманітні відносно легкі порушення розвитку, що характеризуються незрілістю емоційно-вольових та когнітивних функцій 3 перспективою їх розвитку або компенсації.

У XIX ст. відомі психіатри M. Lewis, E. Locke (Lewis, 2006; Locke, 2002) визначають поняття “інфантилізм", під яким розуміють особливу затримку психофізичного розвитку, яка виникає під впливом різних інфекцій і інтоксикацій. У якості основної вірулентної характеристики інфантильних дітей, вченими визначено незрілість емоційно-вольової сфери за типом інфантилізму та труднощі у засвоєнні знань і уявлень на початковому етапі навчання. Інфантилізм виразно простежується в умовах, коли дитина повинна виконувати нові для неї вимоги, зокрема при переході від дошкільного дитинства до шкільного. Тобто, в поняття інфантилізм автори вкладають цілісну структуру фізичних і психічних ознак незрілості, що не властиві дітям такого ж віку з нормотиповим розвитком.

У зарубіжній літературі в контексті соціально-когнітивних теорій, дітей із ЗПР розглядають з одного боку як педагогічно запущених і зазвичай описують їхні потреби як труднощі у навчанні ("educationally disabled", 
mainly due to unfavorable living conditions ("maladjusted"), or as socially deprived ("socially deprived") (McClelland, 1953; Hull, 1943; Semigina \& Chystiakova, 2020). In the field of behavioral research, some authors identify developmental delay with behavioral disorders, others - with developmental disorders that can be traced in learning difficulties and associated with residual (residual) organic brain damage. In subject-activity theories, developmental delay is characterized as specific partial difficulties, which are mainly observed in children in the learning process, in scientific terminology it is "children with hyperactive disorder with attention deficit" syndrome - ("children with attention deficit hyperactivity disorders" - "ADHD syndrome").

Despite the wide variety of developmental delay, children who are classified as this type of dysontogenetic disorders can be characterized as those who do not have pronounced developmental disorders (mental development disorders, severe speech disorders, and severe primary disorders in the functioning of individual analyzer systems - hearing, vision, and motor system). However, on the one hand, these children experience difficulties in social adaptation, including school, due to minor damage to the central nervous system or its functional immaturity, somatic weakness, cerebrastenic states, immaturity of the emotional-volitional sphere such as psychophysical infantilism, and pedagogical neglect as a result of unfavorable socio-pedagogical conditions at the early stages of child development. On the other hand, the difficulties are caused by shortcomings both in the component of mental activity regulation (lack of attention, immaturity of motivational sphere, general cognitive passivity and reduced self-control) and in its operational component (reduced level of development of certain mental processes, motor disorders and work disorders).

Devoted their research to the study of the peculiarities of the mental development of children with CPD and the search for means of corrective and developmental influence (Junthong et al., 2020; Prokhorenko \& Romanenko, 2019; Zasenko \& Prokhorenko, 2018). At the same time, this problem is currently insufficiently studied and quite relevant. "children with learning disabilities"), з іншого визначають, як непристосованих до соціуму, переважно внаслідок несприятливих життєвих умов ("malagjusted"), або як соціально депривованих ("socially deprived") (McClelland, 1953; Hull, 1943; Semigina, Chystiakova, 2020). У полі поведінкових наукових течій окремі автори затримку психічного розвитку ототожнюють 3 порушеннями поведінки, інші - $з$ порушеннями у розвитку, що простежуються в труднощах у навчанні та пов'язані з резидуальними (залишковими) органічними ушкодженнями мозку. У суб'єктно-діяльнісних теоріях затримку психічного розвитку характеризують як специфічні парціальні труднощі, які в основному спостерігаються у дітей в процесі навчання, за науковою термінологією - це "діти з гіперактивним розладом з дефіцитом уваги", синдромом ГРДУ - ("children with attention deficit hyperactivity disorders" - "syndrome ADHD").

Незважаючи на досить широку розмаїтість затримки психічного розвитку, дітей, яких відносять до цього типу дизонтогенетичних порушень, можна охарактеризувати як таких, що не мають виражених відхилень у розвитку (порушень розумового розвитку, з важкими порушеннями мовлення, виражених первинних порушень у функціонуванні окремих систем аналізаторів - слуху, зору, рухової системи). Втім, з одного боку, ці діти зазнають труднощів соціальної адаптації, у тому числі шкільної, внаслідок легких ушкоджень центральної нервової системи або її функціональної незрілості, соматичної ослабленості, церебрастенічних станів, незрілості емоційно-вольової сфери за типом психофізичного інфантилізму, а також педагогічної занедбаності в результаті несприятливих соціально-педагогічних умов на ранніх етапах розвитку дитини. 3 іншого - труднощі зумовлені недоліками як в компоненті регуляції психічної діяльності (недостатністю уваги, незрілістю мотиваційної сфери, загальною пізнавальною пасивністю і пониженим самоконтролем), так і в ії операціональному компоненті (зниженим рівнем розвитку окремих психічних процесів, моторними порушеннями та порушеннями працездатності).

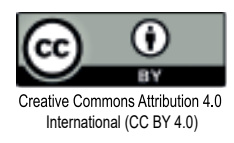


It should be noted that to date there is no common point of view on the characteristics of this category of children. Thus, researchers consider the manifestations inherent in developmental delay as components of intellectual development disorders. According to the authors, these manifestations are characterized by a slow pace of mental development, personal immaturity, gross impairment of cognitive activity, which in structure and quality indicators tend to compensate and develop (Lebedynska, 1980; Lebedynsky, 1985; Chomska, 2000).

Another study characterized children with BPD as lagging behind in their development, while having the potential to develop cognitive and intellectual spheres (Lubovsky, 1989). The scientist emphasizes that developmental delay is overcome the more successfully, the more adequately and earlier special conditions for learning and development are created.

According to many scientists, developmental delay is a polymorphic disorder, as some children may suffer from disability, others from the emotional and volitional sphere, and some motivation for cognitive activity (Lebedinskaya, 1980; Lebedinsky, 1985; Lubovsky, 1989; Chomskaya), 2000; Herman, 2008). At the same time, the variety of manifestations of CPR is also determined by the depth of damage and varying degrees of immaturity of brain structures.

Quite interesting is the fact that in the course of scientific discussions a psychological and pedagogical definition of "developmental delay" was formulated, which is used to identify the most common deviation in psychophysical development that occurs in children (K.Lebedynska,1980;V.Lubovsky,1989).Scientists interpreted the concept of "developmental delay" as a slowdown in mental development, which is most often observed when entering school and is reflected in the lack of general knowledge, limited ideas, and immaturity of thinking, low intellectual focus, and predominance of gaming interests, rapid saturation of intellectual activity etc. However, unlike children with intellectual disabilities, children with SCI are free to use their existing knowledge in practice and much more productive in using the help provided to them. At the same time, there is a delay
Вивченню особливостей психічного розвитку дітей із ЗПР та пошуку засобів корекційно-розвивального впливу присвятили свої дослідження (Junthong et al., 2020; Прохоренко, Романенко, 2019; Zasenko, Prokhorenko, 2018). Водночас, означена проблема на сьогодні $\epsilon$ недостатньо вивченою і досить актуальною.

При цьому слід сказати, що донині відсутня єдина спільна точка зору щодо характеристик означеної категорії дітей. Так, дослідники розглядають прояви притаманні для затримки психічного розвитку як складові порушень інтелектуального розвитку. На думку авторів, ці прояви характеризуються уповільненим темпом психічного розвитку, особистісною незрілістю, негрубими порушенням пізнавальної діяльності, які за структурою та якісними показниками мають тенденцію до компенсації та розвитку (Лебединська, 1980; Лебединський, 1985; Хомська, 2000).

У іншому дослідженні характеризуються діти із ЗПР як такі, що відстають у своєму розвитку, маючи при цьому потенційні можливості розвитку когнітивної та інтелектуальної сфер (Лубовський, 1989). Вчений наголошує, що затримка психічного розвитку долається тим успішніше, чим адекватніше й раніше створюються спеціальні умови для навчання і розвитку.

На переконання багатьох вчених, затримка психічного розвитку є поліморфним порушенням, оскільки у одних дітей може страждати працездатність, у інших - емоційно-вольова сфера, а у когось - мотивація до пізнавальної діяльності (Лебединська, 1980; Лебединський, 1985; Лубовський, 1989; Хомська, 2000; Herman, 2008). При цьому, різноманіття проявів ЗПР визначається також глибиною ушкоджень і різним ступенем незрілості мозкових структур.

Досить цікавим видається той факт, що у процесі наукових дискусій було сформульовано психолого-педагогічне визначення “затримка психічного розвитку", яке вживається для ідентифікації найпоширенішого відхилення у психофізичному розвитку, що зустрічається у дітей (К. Лебединська, 1980; В. Лубовський, 1989). Вчені трактують поняття “затримка психічного розвитку" як 
in the development of the emotional sphere (various types of infantilism), and disorders in the cognitive sphere are not pronounced sharply, in others - on the contrary, there is a slowdown in the development of the cognitive sphere. However, all disorders of intellectual and mental processes in a child are reversible. These differences are overcome in the organization of special conditions of education and upbringing. According to various authors, among the child population there are about $11.0 \%$ of children with BPD of different genesis (Lebedynska, 1980; Lebedynsky, 1985; Lubovsky, 1989).

Analyzing the state of development of the problem of psychological and pedagogical typology of developmental delay of schoolchildren, it should be noted that many researchers attribute to developmental delay "borderline" form of dysontogenesis, which is expressed in the slow maturation of various mental functions. However, in general, this condition is characterized by heterophony (diversity) of manifestations of deviations and significant differences both in their severity and in the prognosis of consequences. Different combinations of certain brain structures, the functions of which are impaired, correlate with different behavioral manifestations: for example, insufficient attention can be combined with inhibition; some cortical lesions, most often in the parietal cortex - are accompanied by immaturity of the system of sensory analysis of higher integrative centers (Chomskaya, 2000).

Significant psychological and pedagogical studies conducted by various scientists have found in children with BPD instability of attention, lack of phonemic hearing, visual and tactile perception, analytical and synthetic processes, motor, sensory, volitional processes, etc. (Lebedinsky, 1985; Lubovsky, 1989; Locke, 2002; McClelland, 1953; Herman, 2008). At the same time, researchers pay attention to a certain partiality, mosaic disorders of certain cortical functions, as a result of which some of these children have difficulty mastering reading, others in writing, still others - arithmetic or find the greatest lack of motor coordination, random memory and more.

Noteworthy is an empirical study, which found that an important element of socialization of adolescents with intellectual disabilities уповільнення темпу психічного розвитку, що найчастіше простежується під час вступу до школи і відбивається в недостатності загального запасу знань, обмеженості уявлень, незрілості мислення, низькій інтелектуальній цілеспрямованості, переважанні ігрових інтересів, швидкій пересиченості в інтелектуальній діяльності тощо. Проте, на відміну від дітей з порушеннями інтелектуального розвитку, діти із ЗПР можуть вільно використовувати наявні знання на практиці і значно продуктивніші у використанні наданої їм допомоги. При цьому у одних дітей спостерігається затримка розвитку емоційної сфери (різні види інфантилізму), а порушення в когнітивній сфері виражені нерізко, у інших, - навпаки, переважає уповільнення розвитку когнітивної сфери. Втім, усі порушення інтелектуальних і психічних процесів у дитини мають оборотній характер. Указані відмінності долаються при організації спеціальних умов навчання і виховання. За даними різних авторів, у дитячій популяції $\epsilon$ близько $11.0 \%$ дітей із ЗПР різного ґенезу (Лебединська, 1980; Лебединський, 1985; Лубовський, 1989).

Аналізуючи стан розробленості проблеми психолого-педагогічної типології затримки психічного розвитку у школярів, слід відзначити, що багато дослідників відносять до затримки психічного розвитку "прикордонну" форму дизонтогенезу, що виражається у сповільненому темпі дозрівання різних психічних функцій. Втім, в цілому, для такого стану $є$ характерними гетерохронність (різночасність) проявів відхилень й істотні відмінності як у ступені їх вираженості, так і у прогнозі наслідків. Різне поєднання тих чи інших структур мозку, функції яких порушено, корелюється із різними поведінковими проявами: до прикладу, недостатня увага може поєднуватися із розгальмованістю; окремі коркові ураження, частіше всього в тім'яних відділах кори - супроводжуватися незрілістю системи сенсорного аналізу вищих інтегративних центрів (Хомська, 2000).

Вагомі психолого-педагогічні дослідження, проведені різними вченими, констатують у дітей із ЗПР нестійкість уваги, недостатність розвитку фонематичного слуху, зорового і тактильного сприймання, аналітико-синтетичних

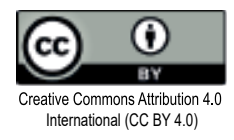


is the correction of their communication in interpersonal relationships (Drozd, Bystrova, 2020).

Summarizing the results of a review of literature sources (Khazova et al., 2019; Lytvynenko et al., 2020; Popovych \&Blynova, 2019; Shipova, N. \& Sevastyanova, 20219), current definitions and interpretations, as well as scientific approaches of leading psychologists on this problem, we can say that developmental delay is one of the most common disorders of psychophysical development of children. This condition covers the entire mental sphere of the child and can be traced in the development of cognitive processes, speech defects, and immaturity of complex behaviors, errors in purposeful activities on the background of excessive exhaustion, disability, encephalopathy disorders and more. All these features affect the course of educational activities of students with developmental delay, and therefore require special conditions for its organization. Therefore, in view of the above, it is fundamentally important to determine the features and specifics of the psychological and pedagogical typology of developmental delay, as a significant factor in the differentiation and individualization of the education of students with special educational needs. Based on the analysis of the most common combinations in the peculiarities of development, we have identified generalized classification features of psychological and pedagogical typology, which are inherent in a particular group of children with developmental delay.

Hypothesis. The authors suggest that the peculiarities of the study of types and the creation of a typology of developmental delay and opportunities for the development of mental processes of students are important components of their educational activities, the implementation of which will contribute to the effective organization of such children.

The purpose of the study is to substantiate theoretically and implement the psychological and pedagogical typology of developmental delay of students; revealing key ways of organizing and optimizing the education of children with different types of developmental delay; formation of recommendations on the most optimal процесів, моторних, сенсорних, вольових процесів тощо (Лебединський, 1985; Лубовський, 1989; Locke, 2002; McClelland, 1953; Herman, 2008). При цьому дослідники звертають увагу на певну парціальність, мозаїчність порушень окремих кіркових функцій, в наслідок чого одні з таких дітей зазнають переважно труднощів в оволодінні читанням, інші - письмом, ще інші - рахунком чи виявляють найбільшу недостатність рухової координації, довільної пам'яті тощо.

Заслуговує уваги емпіричне дослідження, у якому встановлено, що важливим елементом соціалізації підлітків з інтелектуальними порушеннями $є$ корекція їх комунікації в міжособистісних стосунках (Drozd, Bystrova, 2020).

Узагальнюючи результати огляду літературних джерел (Khazova et al., 2019; Lytvynenko et al., 2020; Popovych, Blynova, 2019; Shipova, N., Sevastyanova, 20219), актуальних визначень і тлумачень, а також наукових підходів провідних психологів щодо означеної проблеми можна стверджувати, що затримка психічного розвитку належить до одного 3 найпоширеніших порушень психофізичного розвитку у дітей. Цей стан охоплює усю психічну сферу дитини й простежується в особливостях розвитку когнітивних процесів, вадах мовлення, незрілості складних форм поведінки, хибаху цілеспрямованій діяльності на тлі надмірної виснажуваності, порушеннях працездатності, енцефалопатичних розладах тощо. Усі ці особливості впливають на перебіг навчальної діяльності школярів із затримкою психічного розвитку, відтак потребують спеціальних умов iї організації. Тож, з огляду на сказане, принципово важливим $\epsilon$ визначення особливостей і специфіки реалізації психолого-педагогічної типології затримки психічного розвитку, як значущого чинника диференціації та індивідуалізації навчання школярів 3 особливими освітніми потребами. На основі аналізування найбільш поширених комбінацій в особливостях розвитку ми виокремили узагальнені класифікаційні ознаки психолого-педагогічної типології, які притаманні тій чи іншій групі дітей, у яких спостерігається затримка психічного розвитку.

Гіпотеза. Автори припускають, що особливості дослідження типів і створення типології затримки психічного розвитку та можливості 


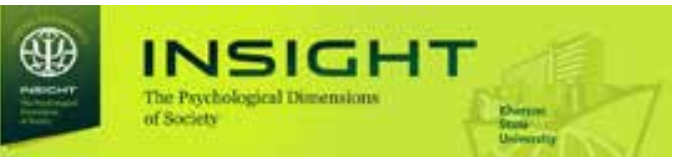

trajectory for choosing an educational institution for them.

\section{Methodology and methods}

Participants. The study involved students with special needs who have signs of developmental delay: Trypillia special boarding school I-II degrees, numbering 25 children (23.8\%); Myrhorod special boarding school of I-III degrees, number of students 35 (33.4\%); municipal institution "Special educational complex of I-II degrees №2" of the Kharkov regional council, the number of students is $45(42.8 \%)$. The total sample consisted of 105 children. The average age of children was 10.5 years (range 7-14 years).

Organization of the study. The study was conducted during 2017-2019. Permission for the empirical study was obtained from the administrations of special educational institutions.

Proceduresand tools. During theschool period a comprehensive psychological and pedagogical assessment of children's development and their ability to learn and based on this assessment developed psychological portraits of children and created conclusions related to the interpretation, explanation of information, reproduction of the overall picture of child development and real level formation of her educational activity.

A set of diagnostic procedures has been carried out in order to fully orientate the subject of study, the level of development of his mental sphere, the formation of educational activities. The survey included purposeful and systematic study of the child'spersonality, cooperation with teachers and psychologists of the educational institution in accordance with the proposed program and included three main stages: information collection, processing and systematization of data, drawing conclusions. Diagnostic tools consisted of the following methods: diagnosis of abnormalities in the intellectual development of primary school children (N. Stadnenko, T. Ilyashenko, A. Obukhovskaya); definition of mental development (Yu. Gilbukh); determination of educational motivation (according to M. Ginzburg); scales of tests of mental development (A. Binet - T. Simon); ADCID: behavior screening (O. Orlov); methods
Prokhorenko Lesia, Kostenko Tetyana

розвитку психічних процесів учнів $є$ важливими складовими їхньої навчальної діяльності, реалізація яких сприятиме ефективній організації навчального процесу таких дітей.

Метою дослідження $\epsilon$ теоретичне обгрунтувати і реалізація психолого-педагогічної типологізації затримки психічного розвитку школярів; розкриття ключових шляхів організації та оптимізації навчання дітей з різними типами затримки психічного розвитку; формування рекомендації щодо найоптимальнішої траєкторії вибору для них навчального закладу.

\section{Методологія і методи Учасники}

у дослідженні брали участь школярі 3 особливими потребами, які мають ознаки затримки психічного розвитку: Трипільської спеціальної загальноосвітньої школи-інтернат I-II ступенів, кількістю 25 дітей (23.8\%); Миргородської спеціальної загальноосвітньої школи-інтернат I-III ступенів, кількістю учнів 35 (33.4\%); комунального закладу “Спеціальний навчально-виховний комплекс I-II ступенів №2" Харківської обласної ради, кількістю учнів 45 (42.8\%). Загальну вибіркову сукупність склали 105 дітей. Середній вік дітей склав 10,5 років (діапазон 7-14 років).

\section{Організація дослідження}

Дослідження проводилося впродовж 2017-2019 рр. На проведення емпіричного дослідження отримано дозвіл і рекомендації від адміністрацій спеціальних закладів освіти.

\section{Процедури та інструменти}

Впродовж навчального періоду проведено комплексну психолого-педагогічну оцінку розвитку дітей та їхньої здатності до навчання й на підгрунті цієї оцінки розроблено психологічні портрети дітей та створено висновки, пов'язані 3 інтерпретацією, поясненням, тлумаченням зібраної інформації, відтворенням загальної картини рівня розвитку дитини та реальним рівнем становлення її навчальної діяльності.

Здійснено комплекс діагностичних процедур, з метою повного орієнтування щодо суб'єкта вивчення, рівня розвитку його психічної сфери, сформованості навчальної діяльності. Обстеження передбачало цілеспрямоване 
of diagnosis of reflection (L. Prokhorenko); differential diagnostic questionnaire (DDO) by E. Klimov.

The aerobatic stage of the research was carried out (related to the testing of selected methods, preliminary orientation in the situation, obtaining initial data for the development of a comprehensive psychological and pedagogical assessment of school-age children). Partial research conducted to study certain areas of the child's psyche for more detailed clarification of problematic issues, such as the formation of self-control, the level of development of which depends on the formation of the intellectual sphere. A step-by-step study included the psychological and pedagogical study of personality in educational activities.

In order to a form the types of developmental delay and determine the conclusions about their implementation in educational activities, three components were identified - motivational, operational, reflexive and evaluative, which took into account: the development of cognitive processes (perception, memory, attention, thinking); level ofintellectualactivity; development of the emotional and volitional sphere; formation of social and communicative skills; learning; motivational readiness for learning.

Blocks of experimental tasks were determined, the performance of which was evaluated from 1 to 10 points: educational motivation 1-10 points (motivational); ability to plan a task, determine the method of its solution, check the course and the end result - 1-10 points and the ability to compare the goal, scheme of action and the end result - 1-10 points (operational); ability to correct performance deficiencies - 1-10 points and adequate selfesteem - 1-10 points (reflexive-evaluative).

Based on a comprehensive psychological and pedagogical assessment, the main problems observed in the studied students were identified: cognitive impairment (memory deficits, difficulty concentrating, thinking disorders) (27.7\%); violation of intellectual processes (12.5\%); neurotic reactions (stress exhaustion, phobic reactions) (5.8\%); functional disorders (behavioral and psychosomatic disorders) (24.6\%); lack of reflection (71.0\%); emotional and behavioral disorders (protest reactions, hyper-hypoactivity, і планомірне вивчення особистості дитини, співпрацю 3 педагогами та психологами освітньої установи згідно з запропонованою програмою і включало три основних етапи: збір інформації, обробку та систематизацію отриманих даних, конструювання висновків. Діагностичний інструментарій складався із наступних методик: діагностики відхилень в інтелектуальному розвитку молодших школярів (Н. Стадненко, Т. Ілляшенко, А. Обухівська); визначення розумового розвитку (Ю. 3. Гільбух); визначення навчальної мотивації (за М. Гінзбургом); шкали тестів розумового розвитку (А. Біне - Т. Сімона); ADCID: скринінг поведінки (О. Орлов); методика діагностики рефлексії (Л. Прохоренко); диференційно-діагностичний опитувальник (ДДО) Є. О. Клімова.

Проведено пілотажний етап дослідження, який пов'язано з випробовуванням підібраних методик, попередньою орієнтацією в ситуації, отриманням вихідних даних для розробки комплексної психолого-педагогічної оцінки дітей шкільного віку. Часткове дослідження проводилося з метою вивчення окремих сфер психіки дитини для більш детального з'ясування проблемних питань, наприклад сформованість самоконтролю, рівень розвитку якого залежить від сформованості інтелектуальної сфери. Комплексний етап дослідження, який передбачав психолого-педагогічне вивчення суб'єкта в навчальній діяльності.

3 метою формування типів затримки психічного розвитку та визначення висновків щодо їх реалізації в навчальній діяльності було визначено три компоненти - мотиваційний, операційний, рефлексивно-оцінний, які враховували: розвиток когнітивних процесів (сприймання, пам'яті, уваги, мислення); рівень інтелектуальної діяльності; розвиток емоційно-вольової сфери; сформованість соціально-комунікативних навичок; научуваність; мотиваційну готовність до навчання.

Визначено блоки експериментальних завдань, виконання яких оцінювалося від 1 до 10 балів: навчальна мотивація - 1-10 балів (мотиваційний); вміння планувати завдання, визначати спосіб його розв'язування, перевіряти хід та кінцевий результат - 1-10 балів 
frequent mood swings) (43.7\%); problems related to communication (lack of adequate social and communication skills, excessive dependence on the opinions of others) (56.6\%); low learning, shortcomings in the perception and assimilation of educational information, lack of motivation to learn (64.0\%).

Statistical analysis. Determination of types of developmental delay of schoolchildren was carried out by cluster analysis by the method of k-means. The method of r-Pearson correlation analysis was used to determine the relationship between motivational, operational and reflexiveevaluative components of educational activity. We consider statistically significant data at $\mathrm{p} \leq .01 ; \mathrm{p} \leq .05$.

\section{Results and discussion}

Clustering is a multidimensional classification of data that contains information about a sample of objects, the purpose of which is to organize the studied objects into relatively homogeneous groups (Popovych, 2014; 2017). Cluster analysis using the $k$-means method combines the parameters of the study of students with developmental delay into separate clusters. We divided $n$ measurements into $k$ clusters, so that each dimension of the subjects belonged to a separate cluster. Next, these clusters formed the content of the proposed typology. Fig. 1 shows the distribution of students to the types of developmental delay.

The first type includes $15.24 \%$ of children who have a relative formation of mental processes, along with reduced cognitive activity, uneven manifestations of cognitive activity and productivity. That is, children with psychophysical infantilism, somatogenous and psychogenic forms of BPD. The analysis of their educational activities revealed that with the appropriate individual approach on the part of the teacher, provided that they attend correctional and developmental classes and with the consent of their parents, these children can be integrated into inclusive education in secondary schools.

The second type accounted for $14.28 \%$ of children with severe intellectual disabilities, along with the formed cognitive activity. These і вміння співставляти мету, схему дій та кінцевий результат - 1-10 балів (операційний); вміння коректувати недоліки виконання 1-10 балів і адекватна самооцінка - 1-10 балів (рефлексивно-оцінний).

На основі комплексної психолого-педагогічної оцінки з'ясовані основні проблеми, які спостерігалися у досліджуваних школярів: порушення когнітивних процесів (недоліки пам'яті, труднощі концентрації уваги, розлади мислення) (27.7\%); порушення інтелектуальних процесів (12.5\%); невротичні реакції (стресове виснаження, фобічні реакції) (5.8\%); функціональні розлади (поведінкові та психосоматичні розлади) (24.6\%); несформованість рефлексії (71.0\%); емоційні та поведінкові порушення (реакції протесту, гіпер-гіпоактивність, часті зміни настрою) (43.7\%); проблеми пов'язані із спілкуванням (несформованість адекватних соціально-комунікативних навичок, надмірна залежність від думок оточуючих) (56.6\%); низька научуваність, недоліки в сприйманні та засвоєнні навчальної інформації, невмотивованість до навчання (64.0\%).

\section{Статистичний аналіз}

Визначення типів затримки психічного розвитку школярів здійснено кластерним аналізом методом $k$-середніх. Для визначення зв'язку між мотиваційним, операційним та рефлексивно-оцінним компонентами навчальної діяльності застосовано метод кореляційного аналізу r-Пірсона. Статистично значущими вважаємо дані при $\mathrm{p} \leq 0.01 ; \mathrm{p} \leq 0.05$.

\section{Результати і дискусія}

Кластеризація $€$ багатомірною класифікацію даних, які містять інформацію про вибірку об’єктів, метою якої $\epsilon$ впорядкування досліджуваних об'єктів у порівняно однорідні групи (Попович, 2014; 2017). Кластерним аналізом методом $k$-середніх об'єднано параметри дослідження школярів 3 затримкою психічного розвитку у окремі кластери. Нами розділено $n$ вимірювань на $k$ кластерів так, щоб кожен вимір досліджуваних належав до окремого кластера. Далі утворені кластери склали зміст запропонованої типологізації. На рис. 1 подано розподіл школярів за типами затримки психічного розвитку. 


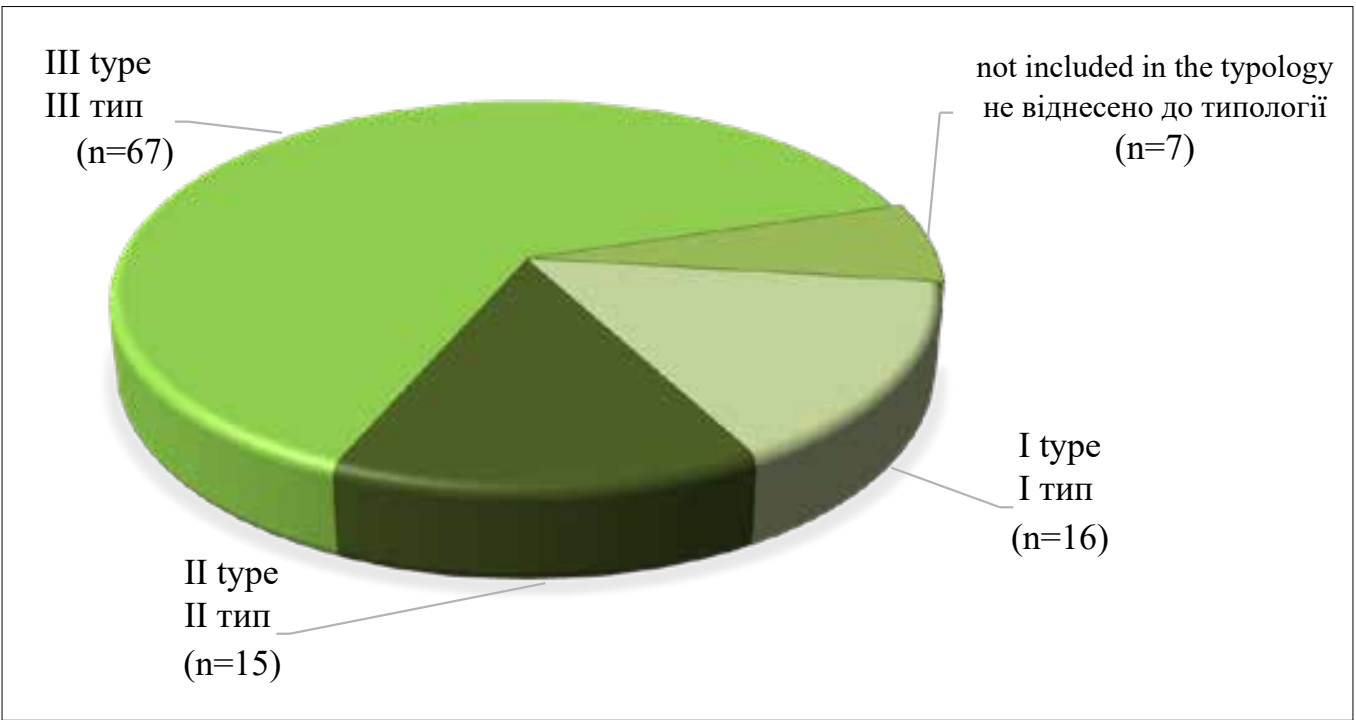

Fig. 1. Distribution of students to the types of developmental delay $(\mathrm{n}=105)$

Рис. 1. Розподіл школярів до типів затримки психічного розвитку (n=105)

are children with cerebral palsy of cerebralorganic origin, in whom there is a pronounced deficiency of certain mental functions (attention, memory, gnosis, praxis). According to the level of educational activity, these children, with proper individual approach by the teacher, providing constant support of the child's assistant and subject to regular attendance of correctional and developmental classes can be integrated into inclusive education in secondary schools after primary education in special schools.

The third type includes $63.81 \%$ of children who have a combination of low level of intellectual productivity and low level of cognitive activity. These are children with severe cerebral palsy of cerebral-organic origin, in whom there is a primary deficiency in the development of all mentalfunctions:attention, memory,gnosis, praxis, as well as underdevelopment of the approximate basis of activity. During the analysis of learning, perception and processing of educational information, on which the effectiveness of educational activities depends, it was found that these children need a proper individual approach, systematic correctional and developmental classes and training in special educational programs in special educational institutions.

And, $6.67 \%$ of students had combined disorders of psychophysical development
До першого типу віднесено 15.24\% дітей, які мають відносну сформованість психічних процесів, поряд зі зниженою пізнавальною активністю, нерівномірні прояви пізнавальної активності і продуктивності. Тобто діти 3 психофізичним інфантилізмом, соматогенною та психогенною формами ЗПР. В ході аналізу їхньої навчальної діяльності було з'ясовано, що при належному індивідуальному підході з боку вчителя, за умови відвідування корекційно-розвивальних занять та за згодою батьків ці діти можуть інтегруватися в умови інклюзивного навчання у загальноосвітні заклади.

Другий тип склали $14.28 \%$ дітей, які мають виражені порушення інтелектуальної продуктивності, поряд із сформованою пізнавальною активністю. Це діти із ЗПР церебрально-органічного генезу, у яких спостерігається виражена дефіцитарність окремих психічних функцій (уваги, пам'яті, гнозиса, праксиса). За рівнем становлення навчальної діяльності ці діти, при належному індивідуальному підході з боку вчителя, забезпеченні постійного супроводу асистента дитини та за умови систематичного відвідування корекційно-розвивальних занять можуть інтегруватися в умови інклюзивного навчання у загальноосвітні школи після закінчення початкової ланки 
and needed individual training, so the developed typology of developmental delay did not apply to these children.

The relationship between motivational, operational and reflexive assessment criteria was statistically established in schoolchildren who demonstrated developmental delay using the $\mathrm{r}$-Pearson correlation analysis at $\mathrm{p} \leq .01$.

Students who are classified as the third type of developmental delay have a low relationship between all components of educational activities (from $r=.13$ to $r=.23$ ): between motivational andoperationalcomponents- $r=.23$, betweenmotivational and reflexive-evaluative $-\mathrm{r}=.13$, between operational and reflexive-evaluative $-\mathrm{r}=.17$. The obtained data testify to insufficiently form of cognitive activity of children. In the course of realization of the available knowledge the interrelations between objects in new conditions of activity are not realized, that is at change of conditions of familiar type of activity construction of a new model is not followed by change of ways and result. The results of the initiated action partially correspond to the plan, due to which the implementation of certain operations can satisfy the condition of activity only at a certain stage, the requirements of which are understood and complied with. In cognitive activity, there is a fixation of knowledge on a set of rules (techniques) that determine the content and sequence of known actions, which ensures a positive result.

The children of the second group had the following results: between the motivational and operational components $-r=.34$, between the motivational and reflexive-evaluative $r=.29$, between the operative and reflexiveevaluative $-r=.31$. This type is based on the awareness and implementation of the optimal options for organizing cognitive actions in a specific and conscious activity. The need to constantly compare the content of their own cognitive actions with a known standard causes their "dissolution" and inability to apply in the context of new activities. Therefore, the regulation of new activities and their results are local in nature.

Children of the first type are focused on selfcontrol. They established a high correlation between the components of self-regulation: between the motivational and operational освіти у спеціальних загальноосвітніх закладах.

У третій тип об’єднано 63.81\% дітей, у яких наявне поєднання низького рівня інтелектуальної продуктивності та низького рівня пізнавальної активності. Це діти з важкою формою ЗПР церебрально-органічного ґенезу, в яких спостерігається первинна дефіцитарність у розвитку всіх психічних функцій: уваги, пам'яті, гнозиса, праксиса, а також недорозвиток орієнтовної основи діяльності. В ході аналізу навчуваності, сприймання та переробки навчальної інформації, від яких залежить ефективність протікання навчальної діяльності, було з'ясовано, що ці діти потребують належного індивідуального підходу, систематичних корекційно-розвивальних занять та навчання за спеціальними навчальними програмами у спеціальних закладах освіти.

I 6.67\% учнів мали комбіновані порушення психофізичного розвитку й потребували індивідуального навчання, тому на цих дітей розроблена типологія затримки психічного розвитку не розповсюджувалася.

Статистично встановлений зв'язок між мотиваційним, операційним та рефлексивно-оцінним критеріями у школярів, які демонстрували затримку психічного розвитку методом кореляційного аналізу r-Пірсона, при $\mathrm{p} \leq 0.01$.

У школярів, які віднесені до третього типу затримки психічного розвитку встановлено низький взаємозв'язок між усіма компонентами навчальної діяльності (від $r=0.13$ до $r=0.23)$ : між мотиваційним і операційним компонентами - $r=0.23$, між мотиваційним і рефлексивно-оцінним - $r=0.13$, між операційним і рефлексивно-оцінним - r = 0.17. Отримані дані свідчать про недостатньо сформовану пізнавальну діяльність дітей. У ході реалізації наявних знань не усвідомлюються взаємозв'язки між об'єктами в нових умовах діяльності, тобто при зміні умов знайомого типу діяльності побудова нової моделі не супроводжуються зміною способів і результату. Результати ініційованої дії частково відповідають задуму, через що реалізація певних операцій може задовольняти умову діяльності лише на певному етапі, вимоги

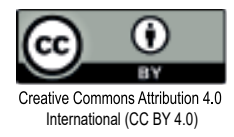


components $-\mathrm{r}=.75$, between the motivational and reflexive-evaluative $-\mathrm{r}=.59$, between the operational and reflexive-evaluative $-r=.85$. In new situations, when the need to comprehend existing algorithms and create new ones, and at the same time the need to fully update thecontentoftheoreticalunderstanding of cognitive actions, namely the focus on self-control, provides adequate orientation regarding reference and transformation of a generalized algorithm allows to a greater or lesser extent to determine the conditions of the new activity, to control the course of the cognitive process and in some way to justify the result. The implementation of such regulatory actions ensures the emergence of a new, acceptable scheme of action, a certain algorithm for solving the problem, a strong hint on how to build a plan.

Thus, interpreting the obtained indicators, it can be argued that the characteristic manifestations thatareembeddedin the specified typology in view of its implementation in educational activities are: underdevelopment of motivational attitude to learning; inability to subordinate one's own activities to goals; low level of goal setting; lack of learning motivation, dominance of close motives aimed at carrying out certain operations and actions; lack of need to overcome difficulties, inability to plan actions and compare them with the imaginary result; inability to determine the stages of the task and the sequence of intermediate goals, especially at those stages that require effort and concentration; unwillingness to improve the result; departure from the ultimate goal, etc.

Consider the essence of psychological and pedagogical types of developmental delay and features of the organization of education of students, which are classified into three types.

The first psychological and pedagogical type of developmental delay includes children with disorders associated with the deficient development of the function of regulation of cognitive activity with initially preserved intellectual development (type I). These are, first of all, states of insufficiency of attention with hyper- or hypoactive disorders of behavior, underdevelopment of motivational and emotional- якого усвідомлено і дотримано. У пізнавальній діяльності спостерігається фіксація знань на сукупності правил (прийомів), які обумовлюють зміст і послідовність відомих дій, що забезпечує отримання позитивного результату.

Діти другої групи мали такі результати: між мотиваційним і операційним компонентами - $\mathrm{r}=0.34$, між мотиваційним і рефлексивно-оцінним - $r=0.29$, між операційним i рефлексивно-оцінним - $\mathrm{r}=0.31$. В основі цього типу - усвідомлення і реалізація оптимальних варіантів організації пізнавальних дій у тій чи іншій конкретній і усвідомленій діяльності. Необхідність постійно зіставляти зміст власних пізнавальних дій з відомим еталоном спричиняє їх "розчинення" і невміння застосовувати в умовах нової діяльності. Тому, регуляція нової діяльності і їі результати мають локальний характер.

Діти першого типу орієнтовані на самоконтроль. У них встановлено високий взаємозв'язок між компонентами саморегуляції: між мотиваційним і операційним компонентами $r=0.75$, між мотиваційним і рефлексивно-оцінним - $r=0.59$, між операційним i рефлексивно-оцінним $-r=0.85$. У нових ситуаціях діяльності, коли на перший план виходить необхідність осмислення діючих алгоритмів і створення нових, а разом з тим і необхідність максимально повно актуалізувати зміст теоретичного осмислення пізнавальних дій, саме орієнтованість на самоконтроль, забезпечує адекватну орієнтацію в умовах еталону та перетворення узагальненого алгоритму, що дозволяє в більшій чи меншій мірі визначити умови нової діяльності, контролювати хід пізнавального процесу та певним чином обгрунтувати отриманий результат. Здійснення таких регулятивних дій забезпечує виникнення нової, прийнятної схеми дій, певного алгоритму щодо розв'язання поставленої проблеми, вагомої підказки щодо шляхів побудови плану.

Таким чином, інтерпретуючи отримані показники можна стверджувати, що характерними проявами, які закладені у означену типологію з огляду на її реалізацію в навчальній діяльності виступають: недорозвиток 
volitional spheres, work disorders of various origins.

In most cases, these disorders can often be the only cause of immaturity of educational and cognitive activities of the child; however, if these disorders are accompanied by primary disorders of organic origin, the cause of persistent failure of the child is complicated by its intellectual retardation. Similar disorders are found in schoolchildren with attention deficit hyperactivity disorder (ADHD). They can also be seen in older preschoolers and firstyear students with typical development (they are associated with immaturity of the central nervous system). This also includes children who have undergone hypo- or hyper protection by their parents (adults), which deepens their difficulties in forming purposeful, arbitrary behavior.

Children classified as psychological and pedagogical type of developmental delay can study in a regular classroom. However, it should be remembered that it is usually very difficult for these children to work in the classroom with the whole class, they show their intellectual potential in the process of individual work only when the teacher organizes and controls their activities.

Overcoming barriers to learning and participation of children with developmental delay type I include an individual approach to such students and, above all, the arrangement of the learning environment. In all forms of work (whole class, group, pair, or individual), the child should be positioned so that he or she can seek help from the teacher at any time and the teacher can observe his or her behavior. When choosing educational tasks, it is necessary to start with the simplest, with which the child can easily cope, or with the repetition of what has already been done and known. At the same time, to control the progress of each stage of the task, to increase the complexity of the tasks gradually, to praise for what has been done - because such children need encouragement the most.

However, it is important to take into account the peculiarities of the child's ability to work. Minimal brain dysfunction is very often accompanied by cerebroasthenic disorders. мотиваційної установки на навчання; невміння підпорядковувати власну діяльність цілям; низький рівень цілепокладання; відсутність навчальної мотивації, домінування близьких мотивів спрямованих на здійснення окремих операцій і дій; відсутність потреби у подоланні труднощів, невміння планувати дії та співставляти їх з уявним результатом; невміння визначати етапи завдання та послідовність проміжних цілей, особливо на тих етапах, що вимагають зусиль і зосередження; небажання покращити результат; відхід від кінцевої мети тощо.

Розглянемо сутність психолого-педагогічних типів затримки психічного розвитку та особливості організації навчання школярів, яких віднесено до трьох типів.

До першого психолого-педагогічного типу затримки психічного розвитку віднесено дітей, у яких спостерігаються порушення пов'язані $з$ дефіцитарним розвитком функції регуляції пізнавальної діяльності при первинно збереженому інтелектуальному розвитку (I тип). Це, насамперед, стани недостатності уваги з гіпер- чи гіпоактивними розладами поведінки, недорозвиненістю мотиваційної та емоційно-вольової сфер, розладами працездатності різного походження.

У більшості випадків ці порушення нерідко можуть бути єдиною причиною несформованості навчально-пізнавальної діяльності дитини. Разом з тим, якщо ці розлади, супроводжуються первинними порушеннями органічного походження, то причина стійкої неуспішності дитини ускладнюється відставанням її в інтелектуальному розвитку. Схожі порушення виявляються у школярів з гіперактивним розладом з дефіцитом уваги (ГРДУ). Також їх нерідко можна спостерігати у старших дошкільників та школярів першого року навчання з типовим розвитком (вони пов'язані з незрілістю центральної нервової системи). Сюди ж відносяться діти, які піддалися гіпо- чи гіперпротекції з боку батьків (дорослих), що й поглиблює їх труднощі у формуванні цілеспрямованої, довільної поведінки.

Діти віднесені до I психолого-педагогічного типу затримки психічного розвитку можуть навчатися у звичайному класі. Втім 
Therefore, children react sharply to changes in meteorological factors (headaches), are overly sensitive to bright light, noise, suffocation. The ability to work of such a student can decline sharply for no apparent reason - in the previous lesson the child behaved well, coped with difficult tasks, and the next - the behavior is inadequate, there is no basic knowledge. Therefore, it is advisable to monitor the child's condition, at this time not to encourage him to do what he should make significant efforts, at the same time, teach the child to control their condition, to warn of ill health, and others.

Wheninvolvingchildreninthefirstpsychological and pedagogical type of developmental delay, it should be remembered that the lack of a sufficient level of individual approach over time will lead to a significant lag in their acquisition of knowledge. The inferiority of educational activities will negatively affect the further development of the child's cognitive sphere - general awareness of the world around will become superficial, lag behind the systematization of knowledge, delay the formation of mental actions and consolidate the negative qualities of thinking. Without proper attention, these children can approach representatives of groups of children with severe learning disabilities due to reduced intellectual development.

The second psychological and pedagogical type of developmental delay includes children with uneven manifestations of educational and cognitive activity and productivity, insufficient intellectual development with a relatively preserved level of their learning, which can be implemented in a specially organized learning.

Children with these disorders are characterized by a sharp limitation of knowledge and ideas about the world around them, unformed mental actions and operations, which can be traced not only in the shortcomings of verbal and logical thinking, but also in perceptual activity, lagging behind in speech development statement). In the process of learning tasks, they experience considerable difficulties due to lack of intellectual skills, speech underdevelopment, but within the available material, they are able to use help, very sensitive to positive stimulation - they become more attentive and productive. слід пам'ятати, що зазвичай цим дітям дуже важко працювати на уроці разом з усім класом, свої інтелектуальні можливості вони виявляють в процесі індивідуальної роботи, лише коли педагог організовує і контролює їхню діяльність.

Подолання бар'єрів в навчанні та участі дітей із затримкою психічного розвитку I типу включає індивідуальний підхід до таких учнів та, насамперед, облаштування навчального середовища. При будь-яких формах роботи (усім класом, групами, парами, чи індивідуально), дитина має розташовуватися так, аби будь-якої хвилини вона могла звернутися по допомогу до вчителя, і вчитель міг спостерігати за ї̈ поведінкою. При доборі навчальних завдань необхідно починати з найпростішого, 3 чим дитина легко впорається, або з повторення вже пройденого і відомого. Водночас контролювати хід виконання кожного етапу завдання, поступово нарощувати складність завдань, хвалити за зроблене, бо такі діти найбільше потребують заохочення.

Втім, важливо брати до уваги особливості працездатності дитини. Мінімальна мозкова дисфункція дуже часто супроводжується цереброастенічними розладами. Тому діти гостро реагують на зміну метеорологічних факторів (головними болями), надмірно чутливі до яскравого світла, шуму, задухи. Працездатність такого школяра може різко знижуватися без видимих причин: на попередньому уроці дитина добре поводилася, справлялася зі складними завданнями, а вже на наступному поведінка неадекватна, відсутні елементарні знання. Тому доцільно відслідковувати стан дитини, у цей час не спонукати робити те, до чого вона має докладати значних зусиль, водночас, вчити дитину самостійно контролювати свій стан, попереджати про погане самопочуття та ін.

Залучаючи до навчання дітей, віднесених до I психолого-педагогічного типу затримки психічного розвитку, слід пам'ятати, - відсутність достатнього рівня індивідуального підходу з часом призведе до суттєвого їх відставання у засвоєнні знань. Неповноцінність навчальної діяльності негативно впливатиме на подальший розвиток пізнавальної 
In a normal classroom, such children are completely unprepared for learning and "drop out" of the learning process. In this regard, they require long-term and systematic correctional and developmental work in a specially organized environment, which involves taking into account the individual capabilities of the child to acquire knowledge and advancement in development. Creating such conditions is possible in an inclusive or integrated classroom.

In an inclusive classroom, the organization of the educational process of the student, with developmental delay of this type, is carried out according to an individual curriculum, based on which an individual curriculum is developed, which determines the content, system of knowledge, skills and abilities to master in the educational process of each subject. During the educational process with the student should be conducted correctional and developmental classes, the number of which is defined in the Individual Development Program and provides a flexible variable structure of its components, namely: individual curriculum, individual program, system of necessary adaptation and modification, a set of additional services would ensure the education of such students in accordance with their capabilities and taking into account additional educational needs.

In developing the Individual Curriculum takes into account state requirements for thelevel of general education of students, especially children with developmental delay, associated with the development of cognitive, educational and subject-practical activities, speech, emotional and volitional sphere, personality, psychomotor development, etc. In an individual curriculum, the content of educational material to be mastered can be reduced (compared to that studied by peers with normative development), but it is important that certain content was sufficient for further study of the subject, and the logic and essence of the content lines of the educational standard was not violated. State requirements for the level of general education, defined in the individual curriculum, can be somewhat simplified and focused on the features of the mental activity of a particular student; characterized by gradual complications; have a clear practical orientation. сфери дитини - загальна обізнаність про навколишній світ ставатиме усе поверховою, відставатиме систематизації знань, затримуватиметься формування розумових дій і закріплюватимуться негативні якості мислення. Без належної уваги ці діти можуть наближатися до представників груп дітей 3 тяжчими порушеннями навчально-пізнавальної діяльності, зумовленими зниженням рівня інтелектуального розвитку.

До II психолого-педагогічного типу затримки психічного розвитку віднесено дітей 3 нерівномірними проявами навчально-пізнавальної активності і продуктивності, недостатнім інтелектуальним розвитком при порівняно збереженому рівні їх научуваності, яка може бути реалізованою в умовах спеціально організованого навчання.

Для дітей з цими порушеннями властивими $\epsilon$ різка обмеженість знань та уявлень про навколишній світ, несформованість розумових дій та операцій, яка простежується не лише в недоліках словесно-логічного мислення, але й у перцептивній діяльності, відставанні в розвитку мовлення (вкрай збідненому словнику, недорозвиненому граматичному висловлюванні). У процесі виконання навчальних завдань вони зазнають чималих труднощів, пов'язаних з відсутністю навичок інтелектуальної роботи, недорозвиненістю мовлення, проте в межах доступного матеріалу вони здатні скористатися допомогою, дуже чутливі до позитивної стимуляції - стають уважнішими і продуктивнішими.

В умовах звичайного класу такі діти виявляються зовсім неготові до навчання і "випадають” з навчального процесу. У зв'язку з цим вони потребують тривалої і систематичної корекційно-розвивальної роботи в спеціально організованих умовах, які передбачають урахування індивідуальних можливостей дитини щодо засвоєння знань і просування в розвитку. Створення таких умов можливе в інклюзивному або інтегрованому класі.

В інклюзивному класі організація навчально-виховного процесу учня, із затримкою психічного розвитку означеного типу, здійснюється за індивідуальним навчальним планом, на основі якого розробляється Індивідуальна 
An important factor that plays a significant role in the education of students with developmental delay is the solution of problems related to the formation of social competence. This is the correction of behavior, the development of the ability to establish social relations and informal emotional and personal relationships with peers, involving the ability to control them and manage their own behavior in various learning situations and group work (including large and small), learn in pairs, work independently, establish relationships with others outside the school. Such skills are considered as long-term goals of correctional and developmental training of a student with developmental delay. Based on the study of the child's socialization interpersonal relationships, behavior during play, in class, out of class - a comprehensive assessment of student behavior, which is taken into account in determining the long-term goal, which outlines the formation of behavior and ability to establish social relations in due time. The outlined goal is specified in the correctional and developmental tasks, which are presented on a separate page of the Individual Child Development Program.

In favorable conditions, children classified as type II psychological and pedagogical, show sufficient learning and a tendency to align in the learning process. As practice shows, many of them during the training in primary school (chain) reaches such a level of development that in the future, under appropriate conditions, can study in the regular classroom.

The third psychological and pedagogical type of developmental delay includes children who are characterized by a combination of low levels of intellectual productivity and excessively weak cognitive activity. Such children are characterized by insufficient intellectual development due to reduced learning. The latter can be traced in a special rigidity, inflexibility of thinking, as a result of which students, faced with difficulties in the process of performing educational tasks, use very little help.

This group includes children with severe developmental delay of cerebral-organic genesis, in whom there is a primary deficiency in the development of all mental functions: attention, memory, gnosis, praxis, etc., as well навчальна програма, що визначає зміст, систему знань, навичок і вмінь, які має опанувати учень в навчальному процесі з кожного предмета. В ході навчального процесу з учнем мають проводитися корекційно-розвивальні заняття, кількість яких визначено у Індивідуальній програмі розвитку й передбачено гнучку варіативну структуру їі складових, а саме: індивідуального навчального плану, індивідуальної навчальної програми, системи необхідних адаптації та модифікації, комплексу додаткових послуг, які б забезпечували навчання таких учнів у відповідності з їхніми можливостями та з урахуванням додаткових освітніх потреб.

При розробленні Індивідуальної навчальної програми беруться до уваги державні вимоги до рівня загальноосвітньої підготовки учнів, особливості дітей із затримкою психічного розвитку, пов'язані із розвитком пізнавальної, навчальної та предметно-практичної діяльностей, мовлення, емоційно-вольової сфери, особистості, психомоторного розвитку та ін. В індивідуальній навчальній програмі зміст навчального матеріалу, що підлягає засвоєнню, може бути скороченим (порівняно 3 тим, що вивчають однолітки з нормотиповим розвитком), водночас важливо аби визначеного змісту було достатньо для подальшого вивчення предмета, а логіка та сутність змістових ліній освітнього стандарту галузі не порушувалася. Державні вимоги до рівня загальноосвітньої підготовки, означені в індивідуальній навчальній програмі, можуть бути дещо спрощені й зорієнтовані на особливості розумової діяльності конкретного учня; характеризуватися поступовим ускладненням; мати виразну практичну спрямованість.

Важливим чинником, що відіграє суттєву роль у навчанні школярів із затримкою психічного розвитку, є розв'язання завдань, пов'язаних із формуванням соціальної компетентності. Це корекція поведінки, розвиток уміння налагоджувати суспільні стосунки i неформальні емоційно-особистісні взаємини з однолітками, що передбачають здатність володіти собою й керувати власною поведінкою у різноманітних навчальних ситуаціях та під час роботи в групі (в тому 
as a clear underdevelopment of the emotional and volitional sphere.

The best conditions for the initial education of such children are an integrated classroom, which uses educational programs for children with developmental delay, where state requirements for the level of general education of students are simplified and focused on the features of cognitive activity of students in this category. It is also advisable to use textbooks and manuals addressed to such students. A significant number of students in this psychological and pedagogical typological group after primary school must continue their education in a special school with curricula for children with developmental delay.

\section{Conclusions}

Typological classification features of developmental delay, by one or another psychological and pedagogical type, and conclusions related to the interpretation, explanation, interpretation of the collected information, reproduction of the general picture of opportunities for development and learning of the child, contain a summary of psychological and pedagogical characteristics of developmental delay development and advice on involving the child in a certain type of educational environment. Of course, the implementation in educational practice of certain psychological and pedagogical types of developmental delay can affect the formation of social ties of the child, its cognitive activity, learning activities and set the tone for psychophysical, personal and social development. However, we hope that the developed psychological and pedagogical typology of developmental delay to involve the child in a certain type of educational environment (stated on the peculiarities of mental development and the formation of cognitive activity of the child) allows expecting a positive prognosis with proper implementation in educational and cognitive activities psychological, pedagogical and methodological organization of the process of learning and development of the child.

Based on the comparison of indicators of motivational, operational and reflexiveevaluation components, statistical relationship числі у великій і малій), навчатися в парах, самостійно працювати, налагоджувати стосунки з оточуючими людьми поза навчальним закладом. Такі уміння розглядаються як довгострокові цілі корекційно-розвивального навчання школяра із затримкою психічного розвитку. На основі даних вивчення особливостей соціалізації дитини - міжособистісних стосунків, особливостей поведінки під час гри, на уроці, поза урочний час, - робиться комплексна оцінка поведінки учня, що береться до уваги при визначенні довгострокової мети, яка окреслює напрями формування поведінки та вміння налагоджувати суспільні стосунки у визначений термін. Окреслена мета конкретизується у корекційно-розвивальних завданнях, які подаються на окремій сторінці Індивідуальної програми розвитку дитини.

У сприятливих умовах діти, віднесені до II психолого-педагогічного типу, виявляють достатню научуваність і тенденцію до вирівнювання у процесі навчальної діяльності. Як засвідчує практика, багато 3 них протягом навчання у початкових класах (ланці) досягає такого рівня розвитку, що в подальшому, за відповідних умов, може навчатися у звичайному класі.

До III психолого-педагогічного типу затримки психічного розвитку віднесено дітей, яким властиве поєднання низького рівня інтелектуальної продуктивності і надмірно слабкої пізнавальної активності. Такі діти характеризуються недостатнім інтелектуальним розвитком, що зумовлено зниженою научуваністю. Остання простежується в особливій ригідності, негнучкості мислення, внаслідок чого учні, стикаючись з труднощами у процесі виконання навчальних завдань, дуже обмежено користуються допомогою.

До цієї групи належать діти з тяжкими формами затримки психічного розвитку церебрально-органічного генезу, в яких спостерігається первинна дефіцитарність у розвитку всіх психічних функцій: уваги, пам'яті, гнозису, праксису тощо, а також наявний виразний недорозвиток емоційно-вольової сфери.

Найкращі умови початкового навчання таких дітей - інтегрований клас, в якому у навчальному процесі використовуються

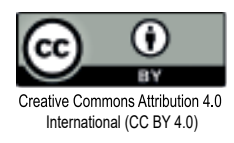


between them and statistically verified different expressions between motivation, self-control, self-esteem, reflection and selfcorrection, psychological and pedagogical types of developmental delay are identified and possibilities of its realization are clarified educational activities. Regarding this typology, the majority of schoolchildren belongs to the II and III types; only $14.28 \%$ of children belong to type I the largest number of students with CPR belongs to type III $-63.81 \%$ of students.

The obtained results will be useful for teachers, psychologists of special and inclusive educational institutions during correctionaland developmental work, determining the features of its content, special methods, methods and conditions that will best promote the acquisition of knowledge and social development of children of one type or another.

\section{References}

Drozd, L. V., Bystrova, Yu. O. (2020). Features of communication of adolescents with intellectual disabilities in the interpersonal relations. Insight: the psychological dimensions of society, 3, 123-133. DOI: $10.32999 / 2663-970 X / 2020-3-9$

Herman, K. (2008). Academic incompetence in first grade as a risk factor for depressive cognitions and symptoms in middle school. Journal of Counseling Psychology, 55, 400-410.

Homskaya, E. (2000). Neuropsychology and psychophysiology of individual differences. Orenburg. OOIPKRO.

Hull, C. (1943). Principles of Behavior. New York. Appleton-Century-Crofts.

Junthong, N., Netpradit, S. \& Boonlue, S. (2020). The designation of geometry teaching tools for visually-impaired students using plastic geoboards created by 3D printing. The New Educational Review, 59(1), 87-102. DOI: 10.15804/tner.2020.59.1.07

Khazova, S., Tikhonova, I., \& Adeeva, T. (2019). Variants of life trajectories among persons with disabilities in the context of subjective well-being and life quality. Social welfare: Interdisciplinary approach, 9(2). 106-115. DOI: 10.21277/sw.v2i9.462

Lebedinskaya, K. (1980). Clinical and psychological analysis of disorders in adolescents. Defectology, $5,3-13$.

Lebedinskiy, V. (1985). Children's mental developmental disorders. Moscow.

Leontev, A. O. (1968). About diagnostic methods of psychological research of schoolchildren. Soviet pedagogy, 7, 65-77. навчальні програми для дітей із затримкою психічного розвитку, де державні вимоги до рівня загальноосвітньої підготовки учнів спрощені й зорієнтовані на особливості пізнавальної діяльності школярів цієї категорії. Також доцільно використовувати підручники та навчальні посібники адресовані саме таким школярам. Значна кількість школярів цієї психолого-педагогічної типологічної групи після початкової школи мають продовжувати навчання в спеціальній школі за навчальними програмами для дітей із затримкою психічного розвитку.

\section{Висновки}

Розроблені типологічні класифікаційні ознаки затримки психічного розвитку за тим чи іншим психолого-педагогічним типом, та створені висновки, пов'язані 3 інтерпретацією, поясненням, тлумаченням зібраної інформації, відтворенням загальної картини можливостей розвитку і навчання дитини, містять сумарну психолого-педагогічну характеристику затримки психічного розвитку та поради щодо залучення дитини до певного типу освітнього середовища. Безумовно, реалізація в освітній практиці виокремлених психолого-педагогічних типів затримки психічного розвитку може по-різному позначатися на формуванні соціальних зв'язків дитини, її пізнавальної активності, навчальної діяльності та задавати тон психофізичному, особистісному і соціальному розвитку. Однак ми сподіваємося, що розроблена психолого-педагогічна типологія затримки психічного розвитку щодо залучення дитини до певного типу освітнього середовища (констатована на особливостях психічного розвитку і формуванні пізнавальної діяльності дитини) дозволяє очікувати на позитивний прогноз при належній їі реалізації в навчально-пізнавальній діяльності при відповідній психолого-педагогічній і методичній організації процесу навчання і розвитку дитини.

На підставі зіставлення показників мотиваційного, операційного і рефлексивно-оцінного компонентів, статистичного взаємозв'язку між ними та статистично завіреної різної вираженості між мотивацією, самоконтролем,

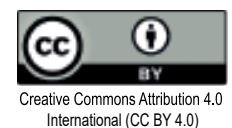


Lewis, M. (2006). The relation of ANS and HPA activation to infant anger and sadness response to goal blockage. Developmental Psychology, 48, 397-405.

Locke, E. (2002). Building a practically useful theory of goal setting and task motivation: A 35-year odyssey. American Psychologist, 57, 705-717.

Lubovskiy, V. (1989). Psychological problems in the diagnosis of abnormal development of children. Moscow: Pedagogy.

Lytvynenko, O., Zlatova, L., Zasenko, V., Prokhorenko, L., Lunov, V. Adaptive Potential of Young People as a Factor of Mental Health-Preserving. Journal of History Culture and Art Research, 2020, 9(3), 374-385. DOI: 10.7596/taksad.v9i3.2846

McClelland, C. The Achievement Motive. New York. Appleton-Century-Crofts, 1953.

Popovych, I. S. \& Blynova, O. Ye. (2019). The Structure, Variables and Interdependence of the Factors of Mental States of Expectations in Students' Academic and Professional Activities. The New Educational Review, 55 (1), 293-306. DOI: 10.15804/tner.2019.55.1.24

Popovych, I. S. (2017) Psychology of social expectations of personality. Doctor's thesis. Severodonetsk: Volodymyr Dahl East-Ukrainian National University.

Popovych, I. S. (2014). Typological features of expectations. KSU Scientific Bulletin, 1(2), 64-70.

Prokhorenko, L. I. \& Romanenko, O. V. (2019). Peculiarities of classification of objects of the information field of children with delay of psychical development. Information Technologies and Learning Tools, 74(6), 266-277. DOI: 10.33407/itlt.v74i6.3395

Prokhorenko, L. (2016). Psychology of self-regulation of schoolchildren with developmental delay. Chernivtsi.

Semigina, T. \& Chystiakova, A. (2020). Children with down syndrome in Ukraine: inclusiveness beyond the schools. The New Educational Review, 59(1), 116-126. DOI: 10.15804/tner.2020.59.1.09

Shipova, N. \& Sevastyanova, U. (2019). Dyadic relations of persons with disabilities: coping and psychological well-being. Social welfare: Interdisciplinary approach, 9(2). 116-126. DOI: $10.21277 /$ sw.v2i9.477

Zasenko, V., Prokhorenko, L. (2019). Educational Development Priorities for People with Special Needs in Ukraine. Education: Modern Discourses, 1, 161-167. DOI: $10.32405 / 2617-3107-2018-1-15$ самооцінкою, рефлексією і самокорекцію визначено психолого-педагогічні типи затримки психічного розвитку та 3'ясовано можливості її реалізації в навчальній діяльності. Відносно цієї типології більшість школярів належать до II i III типів, до I типу належать лише 14.28\% дітей. Найбільша чисельність школярів із ЗПР належать до III типу - 63.81\% учнів.

Отримані результати стануть у нагоді педагогічним працівникам, психологам спеціальних та інклюзивних закладів освіти під час проведення корекційно-розвивальної роботи, визначення особливостей їі змісту, спеціальних методів, способів і умов, які максимально сприятимуть засвоєнню знань і соціального розвитку дітей того чи іншого типу.

\section{Список використаних джерел}

Drozd L. V., Bystrova Yu. O. Features of communication of adolescents with intellectual disabilities in the interpersonal relations. Insight: the psychological dimensions of society, 2020, № 3, P. 123-133. DOI: 10.32999/2663-970X/2020-3-9

Herman K. Academic incompetence in first grade as a risk factor for depressive cognitions and symptoms in middle school. Journal of Counseling Psychology, 2008, № 55, С. 400-410.

Хомская Е. Нейропсихология и психофизиология индивидуальных различий. Оренбург. ООИПКРО, 2000. 234 с.

Hull C. Principles of Behavior. New York. AppletonCentury-Crofts, 1943.240 p.

Junthong N., Netpradit S., Boonlue, S. The designation of geometry teaching tools for visually-impaired students using plastic geoboards created by 3D printing. The New Educational Review, 2020, 59(1), 87-102. DOI: 10.15804/tner.2020.59.1.07

Khazova S., Tikhonova I., Adeeva T. Variants of life trajectories among persons with disabilities in the context of subjective well-being and life quality. Social welfare: Interdisciplinary approach, 2019, 9(2). 106-115. DOI: 10.21277/sw.v2i9.462

Лебединская К. Клинико-психологический анализ нарушений у подростков. Дефектология, 1980, № 5, С. 3-13.

Лебединский В. Нарушение психического развития у детей. Москва, 1985. 167 с.

Леонтьев А. О диагностических методах психологического исследования школьников. Советская педагогика, 1968, № 7, С. 65-77.

Lewis M. The relation of ANS and HPA activation to infant anger and sadness response to goal blockage. Developmental Psychology, 2006, № 48, P. 397-405. 
Locke E. Building a practically useful theory of goal setting and task motivation: A 35-year odyssey. American Psychologist, 2002, № 57, P. 705-717.

Лубовский В. Психологические проблемы диагностики аномального развития детей. Москва. Педагогика, 1989. 104 с.

Lytvynenko O., Zlatova L., Zasenko V., Prokhorenko L., Lunov V. Adaptive Potential of Young People as a Factor of Mental Health-Preserving. Journal of History Culture and Art Research, 2020, 9(3), 374-385. DOI: $10.7596 /$ taksad.v9i3.2846

McClelland C. The Achievement Motive. New York. Appleton-Century-Crofts, 1953.

Popovych I. S., Blynova O. Ye. The Structure, Variables and Interdependence of the Factors of Mental States of Expectations in Students' Academic and Professional Activities. The New Educational Review, 2019, 55(1), 293-306. DOI: 10.15804/tner.2019.55.1.24

Попович I. C. Психологія соціальних очікувань особистості: автореф. дис. ... д-ра психол. наук: 19.00.05. Сєвєродонецьк, 2017. 40 с.

Попович I. С. Типологічні особливості очікувань. Науковий вісник Херсонського державного університету, 2014. Вип. 1. Т. II. С. 64-70.

Прохоренко Л. Психологія саморегуляції школярів із затримкою психічного розвитку. Чернівці, 2016. 520 c.

Прохоренко Л. І., Романенко О. В. Особливості класифікації об’єктів інформаційного поля дітьми із затримкою психічного розвитку. Інформаційні технології $i$ засоби навчання, 2019. T. 74, № 6, 266-277. DOI: $10.33407 /$ itlt. v74i6.3395

Semigina T., Chystiakova A. Children with down syndrome in Ukraine: inclusiveness beyond the schools. The New Educational Review, 2020, 59(1), 116-126. DOI: 10.15804/tner.2020.59.1.09

Shipova N., Sevastyanova U. Dyadic relations of persons with disabilities: coping and psychological well-being. Social welfare: Interdisciplinary approach, 2019, 9(2). 116-126. DOI: 10.21277/sw.v2i9.477

Zasenko V., Prokhorenko L. (2019). Educational Development Priorities for People with Special Needs in Ukraine. Education: Modern Discourses, 2019, № 1, P. 161-167. DOI: 10.32405/2617-3107-2018-1-15 